\title{
Validation of the EORTC QLQ-OES18 Questionnaire in Patients Treated with Radiotherapy
}

\author{
Sezin Y. SARI ${ }^{1}$, Gozde YAZICI ${ }^{1}$, Deniz YUCE ${ }^{2}$, Mustafa CENGIZ ${ }^{1}$, Gokhan OZYIGIT ${ }^{1}$ \\ ${ }^{1}$ Hacettepe University, Faculty of Medicine, Department of Radiation Oncology \\ ${ }^{2}$ Hacettepe University Medical School, Department of Preventive Oncology, Ankara, TURKEY
}

\begin{abstract}
Esophagitis is a very common toxicity of radiotherapy (RT). European Organization for the Research and Treatment of Cancer (EORTC) quality of life questionnaire (QLQ)-OES18 can be used to measure the quality of life (QoL) associated with esophageal symptoms. We aimed to translate and validate this questionnaire in Turkish patients. Patients with head and neck cancer (HNC), lung cancer (LC) or esophageal cancer (EC) were administered the EORTC QLQ-C30 and QLQ-OES18 on the 1st, 15th, and last days of RT and at the 3rd month follow-up. Psychometric properties of reliability, validity, scale structure and responsiveness to change were analyzed. Ninety-seven patients were included in the study. All scores in the QLQ-C30, and all but the reflux scores in the QLQ-OES18 were found to change significantly during and after treatment. All correlations of the QLQ-OES18 scale between the 1st and 15th days, 15th and last days, and all but the trouble with coughing score between the last day and follow-up were significantly different. Correlation levels ranged between 33.5-79.9\%, 48.7-87.2\%, and 0.6-74.8\% at each comparison period, respectively. The reliability was evaluated by Cronbach's alpha at each assessment period, and the result was $0.824,0.889,0.898$, and 0.824 for treatment start, mid-treatment, treatment end, and 3rd month follow-up, respectively. The Turkish version of QLQ-OES18 is a valid tool which can be used independently from the demographic and clinical characteristics of the patients. It is highly reliable to evaluate health-related $Q \circ L$ in patients with esophageal symptoms that are treated for HNC, LC, or EC.
\end{abstract}

Keywords: Esophageal toxicity, Quality of life, Radiotherapy, Validation

ÖZET

\section{Radyoterapi Alan Hastalarda EORTC QLQ-OES18 Anketinin Validasyonu}

Özefajit radyoterapi (RT) alan hastalarda sık görülen bir toksisitedir. Özefageal semptomlar ile ilişkili yaşam kalitesini (YK) ölçmek için European Organization for the Research and Treatment of Cancer (EORTC) YK anketi (QLQ)-OES18 kullanılabilmektedir. Bu çalışmanın amacı bu anketin Türkçe'ye çevirisi ve validasyonu idi. Bu amaçla baş-boyun kanseri (BBK), akciğer kanseri (AK) ve özefagus kanseri (ÖK) tanilı hastalarda RT'nin 1., 15. ve son günlerinde ve RT bitiminden sonraki 3. aydaki kontrolde EORTC QLQ-C30 ve QLQ-OES18 anketleri uygulandı. Güvenilirlik, geçerlilik, ölçek yapısı ve değişikliğe cevapllı̆̆ın psikometrik özellikleri incelendi. Çalışmaya 97 hasta dahil edildi. Bu hastalarda QLQ-C30'daki tüm skorların ve QLQ-OES18'de reflü hariç tüm skorların tedavi boyunca ve ilk kontrolde belirgin olarak değiştiği gözlendi. QLQ-OES18'de 1. ile 15. günler arasında, 15. ile son günler arasında ve son gün ile 3. ay takip kontrolü arasında öksürük dışındaki tüm skorlardaki korelasyonlar belirgin olarak farklı bulundu. Bu dönemler arasındaki korelasyon düzeyleri sırasıyla \%33.5-79.9, \%48.7-87.2 ve \%0.6-74.8 idi. Dönemlerdeki güvenilirlik Cronbach's alfa ile değerlendirildi ve tedavi başı, ortası, sonu ve 3. ay takipte sırasıyla 0.824, $0.889,0.898$ ve 0.824 bulundu. Ayrıca QLQ-OES18'in Türkçe versiyonunun hastaların demografik ve klinik özelliklerinden bağımsız olarak kullanılabileceği de gösterildi. Bu bulgulara dayanarak BBK, AK ve ÖK nedeniyle tedavi edilen hastalardaki özefageal semptomlar ile ilişkili YK'ni değerlendirmek için QLQ-OES18 anketi güvenilirliği yüksek bir yöntemdir.

Anahtar Kelimeler: Özefagus toksisitesi, Yaşam kalitesi, Radyoterapi, Validasyon 


\section{INTRODUCTION}

Esophagitis is a common toxicity in patients that receive radiotherapy (RT) to the esophageal region. During the RT in patients with head and neck cancer (HNC), lung cancer (LC), and esophageal cancer (EC), a substantial volume of the esophagus is irradiated, and esophagitis occur inevitably, which results in dysphagia. Dysphagia can lead to a decrease in oral intake, and can result in serious malnutrition. ${ }^{1}$

Questionnaires have been developed for the measurement of severity of dysphagia and swallowing $^{2-4}$; however, these questionnaires mostly focus on the functions of pharyngeal constructor muscles. The most commonly used questionnaire that measures the quality of life (QoL) associated with esophageal symptoms is the one developed by the European Organization for the Research and Treatment of Cancer (EORTC), and is called the 'Quality of Life Questionnaire-Oesophagus18' (QLQOES18) and used together with the 'QLQ-Core30' (QLQ-C30). The present study aims to validate the use of the QLQ-OES18 in patients whose esophagus is irradiated during RT.

\section{PATIENTS AND METHODS}

\section{Patient Population and Treatment}

The study included 97 patients with HNC, LC, or EC that were treated between December 2012 and August 2016. All patients underwent RT, either adjuvant or definitive, with or without CT. Patients with distant metastasis at the time of diagnosis, or inadequate or no oral intake prior to RT were excluded.

Radiotherapy was administered as the definitive treatment or in the adjuvant setting following surgery. According to the treatment protocol used, some of the patients received induction and/or concurrent $\mathrm{CT}$.

\section{QoL Questionnaires}

Each patient was administered EORTC QLQ-C30 and EORTC QLQ-OES18 on the 1st, 15th, and last days of RT, and at the first follow-up 3 months after the completion of RT. EORTC QLQ-C30 measures general QoL, and can be used alone or together with other questionnaires developed for specific anatomic locations. It includes 3 subscales, i.e. a general health status scale, a functional scale, and a symptom scale. On the other hand, the QLQOES18 is specific for esophageal symptoms, and consists of a symptom scale only. The QLQ-OES18 includes 18 questions: 6 single item subscales relating to saliva swallowing, choking, dry mouth, taste, coughing, and talking. It also includes 12 items grouped into 4 subscales: dysphagia (3 items), eating (4 items), reflux ( 2 items), and pain (3 items). The response format was a four-point Likert scale in both QLQ-C30 and QLQ-OES18. Responses to the questionnaires were transformed into a 0-100 scale using EORTC guidelines. ${ }^{5}$ The decrease in scores of general health status and functional scales in EORTC QLQ-C30 imply deterioration of these scales, whereas the increase in scores of symptom scales in both questionnaires implies deterioration of symptoms.

\section{Validation Process}

For the Turkish translation and validation of the EORTC QLQ-EOS18, we first contacted with the Translation Center of EORTC, and obtained official approval. We followed the translation process recommended by the EORTC. ${ }^{6}$ The EORTC QLQOES18 module consists of 18 questions, of which 15 questions already existed in other EORTC modules, and their translation to Turkish had been approved by the EORTC. However, when we reevaluated these questions, we detected 5 questions that do not correctly meet their English meanings (i.e. 'Could you eat solid food?', 'Could you eat liquidized or soft food?', 'Could you drink liquids?', 'Have you had problems with your sense of taste?', and 'Have you had trouble with coughing?'). Therefore, with the 3 questions that were not translated before (i.e. 'Have you had trouble with swallowing your saliva?', 'Have you had pain when you eat?', and 'Have you had pain in your chest?'), we translated 8 questions in total. All patients completed both questionnaires, and the accrual rate was $100 \%$. 


\begin{tabular}{|ll|}
\hline $\begin{array}{l}\text { Table 1. General demographic and clinical data of the pa- } \\
\text { tients }\end{array}$ & \\
\hline & Mean \pm SD \\
\hline Age (years) & $58.3 \pm 11.5$ \\
Primary tumor dose (cGy) & $6497.1 \pm 601.2$ \\
Volume of the irradiated esophagus (mm3) & $34.5 \pm 23.3$ \\
Mean dose to the esophagus (cGy) & $2139.3 \pm 952.2$ \\
Maximum dose to the esophagus (cGy) & $5726.6 \pm 1350$ \\
& $\mathbf{n}(\%)$ \\
Gender & \\
Female & $12(12)$ \\
Male & $85(88)$ \\
Primary tumor location & \\
Head and neck & $54(56)$ \\
Lung & $36(37)$ \\
Esophagus & $7(7)$ \\
Stage & \\
Stage I & $2(2)$ \\
Stage II & $13(15)$ \\
Stage III & $49(56)$ \\
Stage IV & $24(27)$ \\
Induction chemotherapy & \\
Yes & $41(43)$ \\
No & $55(57)$ \\
Concurrent chemotherapy & \\
Yes & $88(92)$ \\
No & $8(8)$ \\
Yes & $17(18)$ \\
No & $79(82)$ \\
\hline & \\
\hline
\end{tabular}

\section{Statistical Analysis}

Data were presented as median, interquartile range (IQR), and minimum and maximum values for numerical variables, and frequencies and percent for categorical variables. The comparisons of numerical data between independent groups were performed with Mann-Whitney U test for two groups, and Kruskall-Wallis test for more than two groups. The comparisons of numerical data between dependent groups were performed with Friedman test for more than two groups. Correlations of scale scores between assessment periods were performed with Spearman non-parametric correlation analysis. Reliability of the Turkish version of QLQ-OES18 scale was analyzed by Cronbach's alpha, and levels higher than 0.8 was considered as highly reliable. Structural validity and functional validity was checked by comparisons of QLQOES18 scores between important demographic and clinical sub-groups, and the similarities of dif- ferences were confirmed by the similar patterns in QLQ-C30 score comparisons. If one is interested, the detailed analyses for validity checks can be requested from the corresponding author. All statistical analyses were performed with SPSS $21 \AA$ (IBM Corp., Armonk, NY, USA) software, with a two-tailed design, and a type-I error level of $5 \%$.

\section{Ethical Statements}

This study has been carried out in accordance with The Declaration of Helsinki for experiments involving humans. All patients provided written informed consent, and the study protocol was approved by the Hacettepe University Ethics Committee for Non-Invasive Clinical Research (registration number: LUT 12/123; 9 October, 2012).

\section{RESULTS}

This study included a total of 97 patients that received definitive or adjuvant RT and/or CT for malignant diseases including HNC (55.7\%), LC (37.1\%), and EC (7.2\%). Mean age of the patients was $58.3 \pm 11.5$ years, and the majority of the patients $(87.6 \%)$ were male. More than half of the patients had stage III disease $(55.7 \%)$. General demographic and clinical data of the patients are presented in Table 1.

In the health-related QoL assessment via EORTC QLQ-C30 and QLQ-OES18 scales, all scores in the QLQ-C30 scale, and all but the reflux scores in the QLQ-OES18 scale were found to change significantly during treatment and in the followup period (Tables 2 and 3). The symptom scores in both scales increased during the treatment period, and then decreased significantly through the 3rd month follow-up visit. Unlike the symptom scales of QLQ-C30 and QLQ-OES18 (Figures 1 and 2), function scales of QLQ-C30 (Figure 3) decreased during the treatment period, but then increased after the termination of treatment.

The correlations of QLQ-OES18 scores at each assessment with the previous assessment period are presented in Table 4. Accordingly, all correlations between treatment start and mid-treatment, mid-treatment and treatment end, and all but the trouble with coughing score between treatment end 


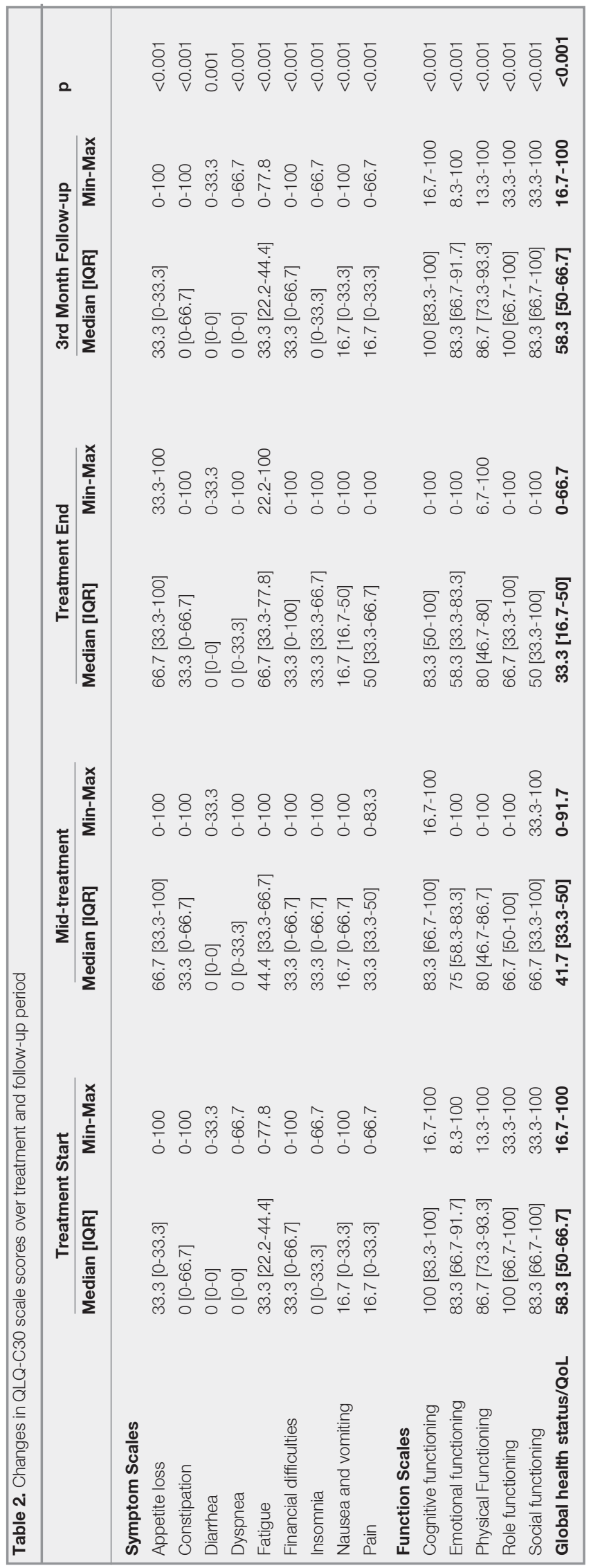

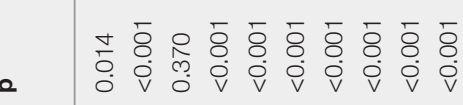

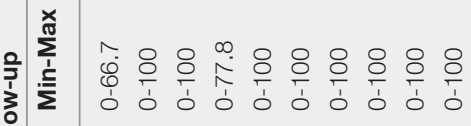

은

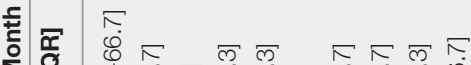

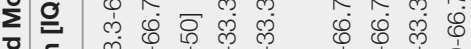

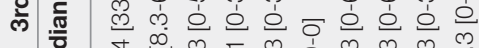

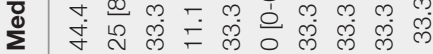

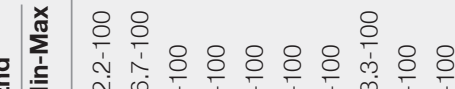

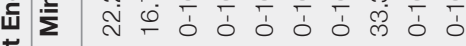

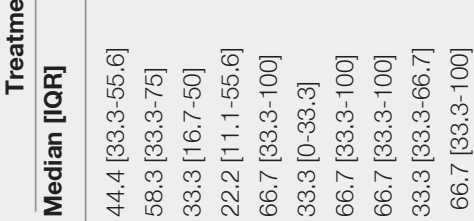

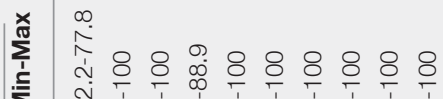

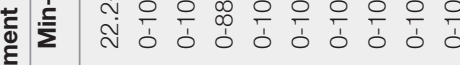

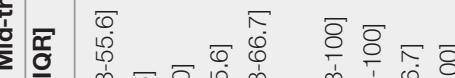

ल ए

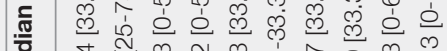

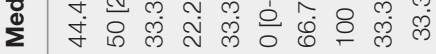

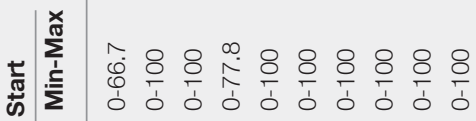
t)

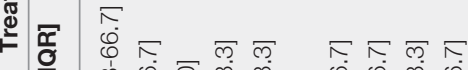

ल कं वं लंख

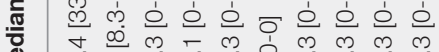
孝岕

UHOD Number: 3 Volume: 27 Year: 2017 


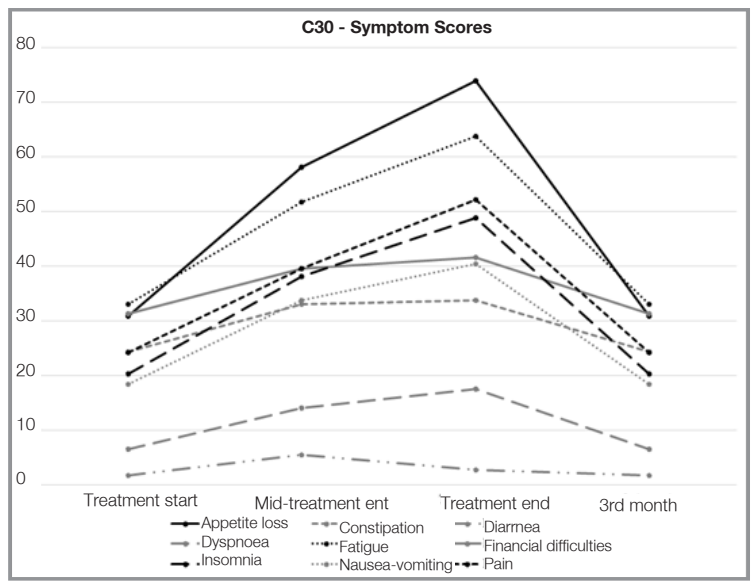

Figure 1. Symptom scores of QLQ-C30

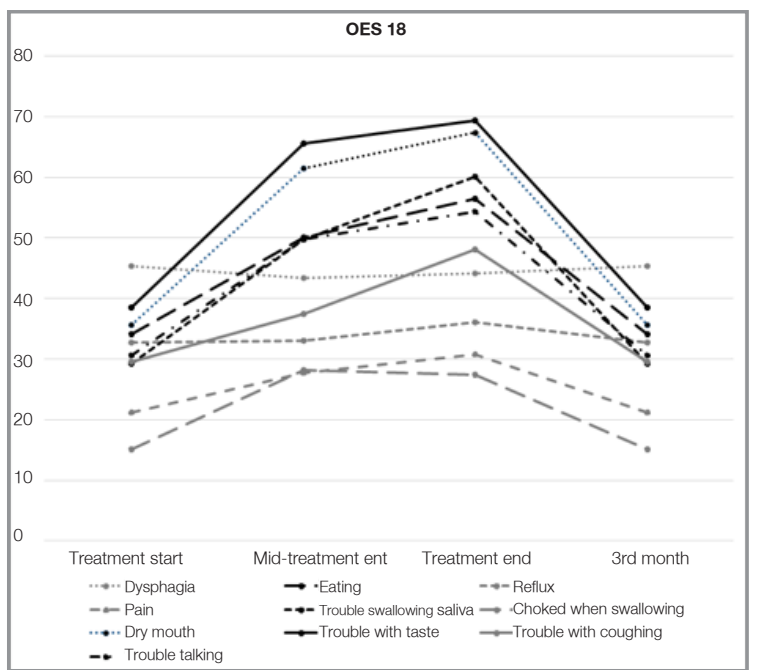

Figure 2. Symptom scores of QLQ-OES18

The validity of the Turkish version of QLQ-OES18 was evaluated by structural and functional validity related analyses. Accordingly, the scale was found to produce similar results between $\mathrm{HNC}, \mathrm{LC}$, and EC, male and female gender, and stages of the diseases. These results revealed that Turkish version of QLQ-OES18 is a valid tool which can be used independently from demographic and clinical characteristics of the patients. Since health-related QoL measurements in these patients aim to evaluate the symptoms of all patients with different characteristics, discriminant validity was not checked for the participants.

\section{DISCUSSION}

In the current study, the QLQ-OES18 was tested for validation in 97 patients with HNC, LC, and EC. All patients fully answered the questionnaire, and they did not complain about any specific question. Significant correlations of QLQ-OES18 scores were detected at the treatment start with mid-treatment, at mid-treatment with the treatment end, and at the treatment end with the 3rd month follow-up. Based on the results of Cronbach's alpha analysis for each assessment period, Turkish version of QLQ-OES18 was found highly reliable to evaluate health-related QoL in patients with HNC, LC, and EC.

The EORTC QLQ-OES18 was developed by Blazeby et al. ${ }^{7}$ to measure the QoL in patients with es- 
Table 4. Correlations of QLQ-OES18 scores between assessment periods

\begin{tabular}{|llll|}
\hline & $\begin{array}{l}\text { Treatment start - } \\
\text { Mid-treatment } \\
\mathbf{r}(\mathbf{p})\end{array}$ & $\begin{array}{l}\text { Mid-treatment - } \\
\text { Treatment end } \\
\mathbf{r}(\mathbf{p})\end{array}$ & $\begin{array}{l}\text { Treatment end - } \\
\text { 3rd Month } \\
\mathbf{r}(\mathbf{p})\end{array}$ \\
\hline Dysphagia & $0.335(0.001)$ & $0.487(<0.001)$ & $0.384(<0.001)$ \\
Eating & $0.516(<0.001)$ & $0.791(<0.001)$ & $0.396(<0.001)$ \\
Reflux & $0.781(<0.001)$ & $0.785(<0.001)$ & $0.62(<0.001)$ \\
Pain & $0.799(<0.001)$ & $0.801(<0.001)$ & $0.748(<0.001)$ \\
Trouble swallowing saliva & $0.52(<0.001)$ & $0.704(<0.001)$ & $0.416(<0.001)$ \\
Choked when swallowing & $0.348(<0.001)$ & $0.872(<0.001)$ & $0.260(0.010)$ \\
Dry mouth & $0.356(<0.001)$ & $0.623(<0.001)$ & $0.517(<0.001)$ \\
Trouble with taste & $0.528(<0.001)$ & $0.812(<0.001)$ & $0.404(<0.001)$ \\
Trouble with coughing & $0.424(<0.001)$ & $0.701(<0.001)$ & $0.006(0.957)$ \\
Trouble talking & $0.605(<0.001)$ & $0.737(<0.001)$ & $0.375(<0.001)$ \\
\hline
\end{tabular}

ophageal cancer treated with surgery, CT, RT and/ or endoscopic intervention. It was called QLQOES 24 when first developed, and it contained 24 questions. The clinical validation and psychometric properties for the reliability and validity of this questionnaire were first assessed in 2003 in 491 newly diagnosed EC patients that underwent curative or palliative treatment. ${ }^{8}$ Based on the responses and feedbacks from the patients, the number of questions was reduced to 18 and the questionnaire was renamed as 'QLQ-OES18'. In this study, Cronbach's alpha coefficient was lowest in the reflux and pain scales, highest in the eating and dysphagia scales, and it was above 0.70 in $60 \%$ of all scales. By the time this questionnaire was assessed for reliability, it had already been available in 13 languages.

Following this study, two groups validated this questionnaire, and reported in the literature. In 2010, the Taiwan Chinese version of the questionnaire was validated in 95 patients with EC. ${ }^{9}$ In this study, the results of 31 patients on-treatment were compared to those of 64 patients off-treatment. The patients on-treatment had significantly higher scores in scales relating to dysphagia, taste, dry mouth, and cough; but lower scores in scales relating to reflux and choking. The other validation of the QLQ-OES18 was reported in 2016 by Fujita et al. ${ }^{10}$ in 50 patients with EC. This Japanese validation compared the results of patients after thoracolaparoscopic and open esophagectomy, and they found a significant reduction in the values of pain scale with the thoracoscopic approach.
To the best of our knowledge, the current study is the third study in the English literature that reported the validation of the QLQ-OES18. Both the previous studies were only held in patients with EC, but our study also includes patients with HNC and LC, also in which RT can lead to esophageal symptoms. The number of patients in our study is similar to those reported earlier. However, we did not assess the correlation between the scales of the QLQ-C30 and QLQ-OES18.

As a conclusion, the current study reveals that the Turkish version of the EORTC QLQ-OES18 can be used to assess the QoL related to esophageal symptoms not only in patients with EC, but also with $\mathrm{HNC}$ and LC. The questionnaire is validated in both genders and all stages of the mentioned malignancies.

\section{REFERENCES}

1. Shah HK, Khuntia D, Hoffman HT, Harari PM. Hypopharynx Cancer. In: Principles and practice of radiation oncology. Halperin EC, Perez CA, Brady LW (eds). 5th edition. Lippincott Williams \& Wilkins, Philadelphia, 2008: 958-974.

2. Levendag PC, Teguh DN, Heijmen BJ. Oropharynx. In: Principles and Practice of Radiation Oncology. Halperin EC, PErez CA, Brady LW (eds). 5th edition. Lippincott Williams \& Wilkins, Philadelphia, 2008: 913-957.

3. Finizia C, Rudberg I, Bergqvist H, Ryden A. A cross-sectional validation study of the Swedish version of SWAL-QOL. Dysphagia 27: 325-335, 2012. 
4. Dwivedi RC, St Rose S, Roe JW, et al. Validation of the Sydney Swallow Questionnaire (SSQ) in a cohort of head and neck cancer patients. Oral Oncology 46: e10-14, 2010.

5. Fayers PM, Aaronson NK, et al., on behalf of the EORTC Quality of Life Group. The EORTC QLQ-C30 Scoring Manual. 3rd edition. Brussels, European Organisation for Research and Treatment of Cancer, 2001.

6. Dewolf L, Koller M., Velikova G, et al. on behalf of the EORTC Quality of Life Group. EORTC quality of life group translation procedure. 3rd edition. Brussels, European Organisation for Research and Treatment of Cancer, 2009.

7. Blazeby JM, Alderson D, Winstone K, et al. Development of an EORTC questionnaire module to be used in quality of life assessment for patients with oesophageal cancer. The EORTC Quality of Life Study Group. Eur J Cancer 32A: 19121917, 1996.

8. Blazeby JM, Conroy T, Hammerlid E, et al. Clinical and psychometric validation of an EORTC questionnaire module, the EORTC QLQ-OES18, to assess quality of life in patients with oesophageal cancer. Eur J Cancer 39: 1384-1394, 2003.

9. Chie WC, Tsai CJ, Chiang C, Lee YC. Quality of life of patients with oesophageal cancer in Taiwan: validation and application of the Taiwan Chinese (Mandarin) version of the EORTC QLQ-OES18: a brief communication. Qual Life Res 19: 11271131, 2010.

10. Fujita T, Okada N, Sato T, et al. Translation, validation of the EORTC esophageal cancer quality-of-life questionnaire for Japanese with esophageal squamous cell carcinoma: analysis in thoraco-laparoscopic esophagectomy versus open esophagectomy. Jpn J Clin Oncol 46: 615-621, 2016.

\section{Correspondence:}

Dr. Sezin YÜCE SARI

Hacettepe Üniversitesi Tip Fakültesi

Radyasyon Onkolojisi Anabilim Dali

Sihhiye 06100

ANKARA / TURKEY

Tel: (+90-312) 3052900

e-mail: sezin_yuce@hotmail.com 